\title{
KARAKTERISTIK KOLAGEN LARUT ASAM TERIPANG GAMA (Stichopus variegatus)
}

\author{
Mega Safithri ${ }^{1,3 *}$, Kustiariyah Tarman ${ }^{2,3}$, Pipih Suptijah ${ }^{2,3}$, Sri Novita Sagita ${ }^{1}$ \\ ${ }^{1}$ Departemen Biokimia, Fakultas Matematika dan Ilmu Pengetahuan Alam, Institut Pertanian Bogor, \\ Kampus IPB Darmaga, Jalan Agatis, Kabupaten Bogor 16680 Jawa Barat Telepon 02518423267 \\ ${ }^{2}$ Departemen Teknologi Hasil Perairan, Fakultas Perikanan dan Ilmu Kelautan, IPB, Jalan Agatis, Kampus \\ IPB Dramaga, Kabupaten Bogor, 16680 Jawa Barat Telepon 02518622915 \\ ${ }^{3}$ Divisi Bioteknologi Kelautan, Pusat Kajian Sumberdaya Pesisir dan Lautan, \\ Lembaga Penelitian dan Pengabdian Kepada Masyarakat, Institut Pertanian Bogor \\ ^Korespondensi: safithri@apps.ipb.ac.id
}

Diterima: 12 Januari 2020/Disetujui: 30 April 2020

Cara sitasi: Safithri M, Tarman K, Suptijah P, Sagita SN. 2020. Karakteristik kolagen larut asam teripang gama (Stichopus variegatus). Jurnal Pengolahan Hasil Perikanan Indonesia. 23(1): 166-177.

\begin{abstract}
Abstrak
Kolagen dibutuhkan pada berbagai industri farmasi, makanan, dan kosmetik, sehingga memiliki nilai ekonomis yang tinggi. Komoditas perikanan terutama teripang gama dapat digunakan sebagai sumber kolagen yang halal. Tujuan penelitian ini adalah untuk menentukan karakteristik fisikokimia kolagen larut asam teripang gama. Perlakuan untuk mendapatkan protein kolagen dilakukan dengan misahankan protein non kolagen menggunakan perendaman dalam $\mathrm{NaOH} \mathrm{0,1} \mathrm{M} \mathrm{selama} 48$ jam kemudian di netralisasi. Tahap selanjutnya dilakukan hidrolisis dan ekstraksi protein kolagen dengan asam asetat $0,5 \mathrm{M}$ selama 48 jam. Hasil pemisahan protein non kolagen menunjukkan kadar protein non kolagen sebesar $0,02 \mathrm{mg} / \mathrm{mL}$. Rendemen kolagen teripang gama yang didapat sebesar 2,4\%. Kolagen larut asam teripang gama memiliki karakteristik fisik yaitu, derajat putih $61,83 \%$, suhu denaturasi pada $48^{\circ} \mathrm{C}$, suhu transisi pada $87,80^{\circ} \mathrm{C}$, dan suhu pelelehan pada $162,40^{\circ} \mathrm{C}$, serta viskositas $5,37 \mathrm{cP}$. Karakter kimia kolagen larut asam teripang gama yaitu $\mathrm{pH}$ 6,12 denganjenis asam amino penyusun kolagen, yaitu prolina 6,80\%, alanina 10,61\% dan glisina 12,63\%, serta bilangan gelombang FTIR gugus fungsi yaitu amida I (1657,9), II (1572,0), dan III $(1242,2)$ A $(3406,3)$, dan B $(2920,2)$ $\left(\mathrm{cm}^{-1}\right)$.
\end{abstract}

Kata kunci: asam amino, derajat putih, fisikokimia, FTIR, viskositas

\section{Characteristics of Stichopus variegatus acid solution collagen}

\begin{abstract}
Collagen is needed in various pharmaceutical, food and cosmetics industries, so it has high economic value. Fishery commodities especially Stichopus variegatus can be used as a halal source of collagen. The purpose of this study was to characterize physicochemical properties of S.variegatus acid soluble collagen. The isolation of collagen consisted of the separation of non-collagen proteins using $0.1 \mathrm{M} \mathrm{NaOH}$ solution and the hydrolysis of collagen using $0.5 \mathrm{M} \mathrm{CH}_{3} \mathrm{COOH}$ for 48 hours. The $S$. variegatus contained $0.02 \mathrm{mg} / \mathrm{mL}$ of the non-collagen proteins. The yields of S. variegatus collagen was $2.4 \%$. The physical characteristics of soluble acid collagen were whiteness degree $61.83 \%$, denaturation temperature $48^{\circ} \mathrm{C}$, transition temperature $87.80^{\circ} \mathrm{C}$, melting temperature $162.40^{\circ} \mathrm{C}$, and viscosity $5.37 \mathrm{cP}$. The identification of chemical characteristics of S.variegatus soluble acid collagen showed that the collagen had $\mathrm{pH}$ 6.12, and the yield of three amino acids that form the collagen were proline $6.80 \%$, alanine $10.61 \%$ and glycine $12.63 \%$. The FTIR wave number of the amide function showed group I (1657.9), II (1571.9), and III (1242.1) A (3406.2), and B (2920.2) $\left(\mathrm{cm}^{-1}\right)$.
\end{abstract}

Keywords: amino acid, FTIR, viscosity, physicochemical, whiteness 


\section{PENDAHULUAN}

Kolagen komersial yang beredar di pasar sebagian besar bersumber dari dari jaringan tulang dan kulit sapi dan babi (Choi et al.2013) yang tidak sesuai dengan keyakinan agama (Hidayat dan Siradj 2015) dan menimbulkan dampak buruk terhadap kesehatan (Silvipriya et al. 2015). Komoditas perikanan menjadi salah satu alternatif sumber kolagen yang berdampak baik terhadap kesehatan dan halal, karena selain digunakan sebagai bahan pangan juga banyak dimanfaatkan sebagai bahan biofarmaka. Komoditas perikanan yang saat ini mulai banyak dimanfaatkan salah satunya adalah teripang. Menurut Purcell (2014) kandungan kolagen yang terdapat dalam teripang mencapai $86 \%$ dari total protein pada tubuh teripang. Isolasi kolagen dari berbagai jenis teripang cukup banyak dilakukan, di antaranya isolasi kolagen dari Stichopus japonicas (Cui et al. 2007), Stichopus vastus (Abedin et al. 2012), dan Stichopus hermanii (Safithri et al. 2018).

Industri kosmetik, obat-obatan, dan pangan mengaplikasikan kolagen dalam bentuk produk yang memiliki nilai ekonomis tinggi. Andiristanti (2012) melaporkan ekstraksi kolagen dari teripang emas (Stichopus hermanii) dan diaplikasikan untuk pelembab kulit. Kualitas kolagen yang digunakan oleh industri harus memiliki karakteristik dan mutu dengan metode yang sesuai standar, sehingga diperlukan pengembangan metode isolasi dari teripang. Karakteristik kolagen ditentukan dari proses isolasi yang digunakan. Metode ekstraksi kolagen yang telah dilakuakan pada hasil perikanan di Indonesia di anataranya menggunakan asam (Wulandari et al. 2015; Djailani et al. 2016; Astiana et al. 2016; Kartika et al. 2017; Pamungkas et al. 2018; Safithri et al. 2019), air (Kartika et al. 2017; Devi et al. 2017; Sitepu et al. 2019, serta bantuan enzimatis (Pamungkas et al. 2018; Nurilmala et al. 2019; Simamora et al. 2019).

Kolagen teripang gama (Stichopus variegatus) berhasil diekstraksi menggunakan metode air pada suhu $40^{\circ} \mathrm{C}$ (Alhana et al. 2015). Metode ekstraksi air menggunakan banyak peralatan laboratorium dan waktu yang cukup lama, sedangkan untuk untuk teripang gama dengan metode ekstraksi larutan asam belum dilakukan. Tujuan penelitian ini adalah untuk menentukan karakteristik fisik dan kimia kolagen larut asam teripang gama.

\section{BAHAN DAN METODE Bahan dan Alat}

Teripang gama (S.variegatus) yang digunakan dalam penelitian ini didapatkan dari Nusa Tenggara Timur, Labuan Bajo. Bahan-bahan kimia yang digunakan adalah Natrium hidroksida (Sigma Aldrich) dan asam asetat $80 \%$ (Sigma Aldrich), albumin serum sapi (Sigma Aldrich) dan pereaksi Bradford (Sigma Aldrich). Instrumen yang digunakan adalah spektrofotometer (Thermo Scientific Genesys 10 UV), viskometer (Brookfield), kromameter (Lutron RGB 1002), dan termal differential scanning calorimatry (DSC-60 Shimadzu), neraca analitik (FS-Ar 210), pH meter (Hanna Instruments), freeze dry (Christ Alpha 2-4 LD UK), Spektroskopi Fourier Transform Infrared (Bruker Tensor 37 German), UPLC (ELSD Waters Acquity H-Class).

\section{Metode Penelitian \\ Preparasi teripang gama}

Teripang yang diperoleh dicuci sampai bersih dari pasir kemudian dimasukkan ke pendingin beku. Pengiriman teripang gama beku menggunakan jasa Argodan dengan mempertahankan suhu dingin dalam kotak stereofoam yang diberi es, sehingga sampel teripang gama diterima di Lab dalam kondisi beku. Preparasi daging teripang gama merujuk pada preparasi daging teripang emas Safithri et al. (2018) dengan mencuci bersih kulit teripang gama, sehingga kotoran yang menempel hilang. Teripang gama yang telah bersih dibelah menggunakan pisau, lalu daging dipisahkan dari jeroan, gonad, dan kulit.

\section{Pemisahan protein bukan kolagen}

Pemisahan protein non kolagen teripang gama menggunakan metode Safithri et al. (2018) dengan modifikasi. Larutan $\mathrm{NaOH} 0,1$ $\mathrm{M}$ (perbandingan 1:10 (b/v)) digunakan untuk merendam daging teripang gama selama 48 jam, setiap 6 jam larutan $\mathrm{NaOH}$ diganti 
dan diuji kadar protein larutan tersebut menggunakan uji Bradford. Hal ini dilakukan untuk menentukan konsentrasi protein non kolagen pada larutan $\mathrm{NaOH}$ dan lama waktu perendaman terbaik, untuk menghilangkan protein yang bukan kolagen.

\section{Hidrolisis kolagen dengan larutan asam}

Hidrolisis kolagen dilakukan berdasarkan metode Safithri et al. (2018). Daging teripang gama hasil pemisahan protein non kolagen yang diperoleh, selanjutnya direndam pada suhu $4^{\circ} \mathrm{C}$ selama 48 jam menggunakan larutan $\mathrm{CH}_{3} \mathrm{COOH}$ 0,5 M. Rasio daging teripang gama dengan $\mathrm{CH}_{3} \mathrm{COOH}$ yang digunakan adalah 1:2 (b/v). Selanjutnya, rendeman disaring memakai kertas saring Whatman, dan dihasilkan protein kolagen bewujud cair, kemudian kolagen padat didapat dengan cara dikering-bekukan (freeze dry).

\section{Metode Analisis \\ Pengukuran kadar protein}

Pengukuran kadar protein bukan kolagen teripang gama memakai metode Bradford (1976). Albumin serum sapi (BSA) digunakan untuk standar protein. Larutan rendaman $\mathrm{NaOH}$ dipipet $100 \mu \mathrm{L}$ dan dimasukkan ke dalam tabung reaksi, lalu reagen Bradford ditambahkan sebesar $5 \mathrm{~mL}$, dan selama 5 menit larutan tersebut diinkubasi pada suhu ruang, lalu dilakukan pengukuran serapannya dengan spektrofotometer pada $\lambda 610 \mathrm{~nm}$. Konsentrasi larutan standar yang dipakai adalah $0 ; 400 ; 500 ; 600 ; 800 ; 1.000$; dan 1.200 $\mu \mathrm{g} / \mathrm{mL}$. Pengukuran kadar protein standar dan sampel dilakukan triplo.

\section{Pengukuran rendemen kolagen}

Pengukuran nilai \% rendemen kolagen teripang menggunakan metode AOAC (2005). Perhitungan \% rendemen kolagen didapat dengan rasio bobot kering kolagen hasil isolasi dengan bobot bahan baku daging sebelum diisolasi. Perhitungan \% rendemen kolagen menngunakan rumus:

Rendemen kolagen $(\%)=\frac{\text { Bobot kering kolagen }}{\text { Bobot bahan baku }} \times 100 \%$

\section{Pengukuran pH}

Pengukuran $\mathrm{pH}$ kolagen menggunakan prosedur AOAC (2005). Satu gram kolagen teripang gama dilarutkan dalam $50 \mathrm{~mL}$ akuades lalu dihomogenkan. Instrumen $\mathrm{pH}$ meter dihidupkan lalu dikalibrasi menggunakan standar larutan $\mathrm{pH} 7$ dan $\mathrm{pH}$ 4, selanjutnya elektroda dicelupkan ke gelas piala yang berisi larutan kolagen, dan diukur nilai $\mathrm{pH}$-nya.

\section{Pengukuran viskositas}

Pengukuran viskositas menggunakan prosedur analisis Safithri et al. (2019). Larutan asam asetat $0,5 \mathrm{M}$ sebanyak $300 \mathrm{~mL}$ digunakan untuk melarutkan kolagen teripang gama dengan konsentrasi $0,3 \% \quad(\mathrm{~b} / \mathrm{v})$. Larutan kolagen yang telah homogen sebanyak 250 $\mathrm{mL}$ diukur viskositasnya. Instrumen yang digunakan adalah viskometer Brokkfield dengan spindle no.2 pada $100 \mathrm{rpm}$.

\section{Pengukuran derajat putih}

Pengukuran derajat putih kolagen teripang menggunakan prosedur analisis Park (2005). Kolagen teripang sebanyak $1 \mathrm{~g}$ ditempatkan pada kertas putih. Pengambilan foto menggunakan kromameter (Lutron RGB 1002) dikerjakan triplo. Angka digital di kromameter menunjukkan hasil analisis. Sistem warna Hunter $L^{*}$ digunakan untuk menilai kecerahan sampel (warna kromatik, 0: hitam hingga 100: putih). Notasi Hunter $\mathrm{a}^{*}$ digunakan untuk warna kromatik merah sampai hijau (0 hingga 100 menunjukkan merah; 0 hingga -80 menunjukkan hijau). Notasi Hunter $b^{*}$ digunakan untuk warna kromatik biru sampai kuning (0 hingga 70 untuk kuning; 0 hingga -70 untuk biru).

Rumus perhitungan derajat putih adalah:

Derajat putih $=100-\left[\left(100-L^{\star}\right) 2+a^{\star} 2+b^{\star} 2\right]^{1 / 2}$

\section{Penentuan gugus fungsi menggunakan alat FTIR}

Penentuan gugus fungsi menngunakan alat FTIR sesuai prosedur analisis Safithri et al. (2018). Kolagen teripang sebanyak $0,02 \mathrm{~g}$ dan $0,1 \mathrm{~g}$ kalium bromida dihaluskan menggunakan mortar sampai homogen. Campuran dimasukkan ke mesin pencetak 
pelet untuk dicetak, lalu divakum. Serapan bilangan gelombang dari kolagen teripang dideteksi pada bilangan gelombang sekitar 4000-500 $\mathrm{cm}^{-1}$. Spektrum tersebut dianalisis untuk menentukan gugus-gugus fungsi protein pada kolagen teripang.

\section{Pengukuran konsentrasi asam amino}

Pengukuran konsentrasi asam amino menggunakan prosedur analisis AOAC (2005). Tahap awal kolagen dihidrolisis menggunakan larutan $\mathrm{HCl} 6 \mathrm{~N}$ dan dipanaskan $100^{\circ} \mathrm{C}$, lalu hidrolisat dikeringkan. Hidrolisat kering diderivatisasi menggunakan larutan phenylisothiocyanat, lalu sampel disaring menggunakan kertas saring ukuran $0,45 \mu \mathrm{L}$ kemudian diinjeksikan ke dalam UPLC. Fase gerak yang digunakan adalah asetonitril. Rumus yang digunakan untuk menghitung konsentrasi asam amino adalah :

Konsentrasi asam amino $=\frac{\text { luas area sampel } \times \mathrm{C} \times \mathrm{FP} \times \mathrm{BM} \times 1 \mathrm{OO}}{\text { luas area sandar } \times \text { bobot sampel }(\mathrm{g})}$

C : Konsentrasi standar asam amino (ug/ $\mathrm{mL})$

FP : Faktor pengenceran

BM : Bobot molekul setian asam amino (g/ mol)

\section{Penentuan titik leleh}

Penentuan titik leleh menngunakan prosedur analisis Martianingsih dan Atmajaya (2009). Instrumen Differential Scanning Calorimetry (DSC) digunakan untuk analisis titik leleh, sehingga diketahui karakteristik termal dari kolagen yag dihasilkan. Sebanyak 0,005-0,01 g kolagen diletakkan dalam tempat berbahan aluminium, kemudian ditutup. Setelah itu alat DSC dikondisikan untuk memiliki kecepatan pemanasan $10^{\circ} \mathrm{C} /$ menit pada suhu $20^{\circ} \mathrm{C}-300^{\circ} \mathrm{C}$.

\section{HASIL DAN PEMBAHASAN Rendemen Kolagen dan Konsentrasi Protein Non Kolagen}

Daging teripang gama direndam selama 48 jam dalam larutan basa $\mathrm{NaOH}$ dan setiap 6 jam larutan basa tersebut diganti. Konsentrasi protein bukan kolagen daging teripang gama cukup tinggi yaitu, $0,107 \mathrm{mg} / \mathrm{mL}$ yang didapat setelah perendaman $\mathrm{NaOH} 6$ jam pertama, dan ada penurunan jumlah protein bukan kolagen pada 6 jam berikutnya. Kadar protein bukan kolagen $0,023 \mathrm{mg} / \mathrm{mL}$ diperoleh setelah 48 jam sampel direndam dalam larutan basa $\mathrm{NaOH}$ (Table 1). Penggunaan larutan $\mathrm{NaOH}$ dalam merendam daging teripang gama bertujuan untuk menghilangkan komponen bukan kolagen, di antaranya protein non kolagen (enzim dan fibrinogen), lemak, mineral, pigmen, dan odor.

Larutan $\mathrm{NaOH}$ dapat menyebabkan daging teripang mengalami pengembangan (swelling) sehingga mempermudah pelarutan protein non kolagen pada daging teripang (Potaros et al. 2009). Pengembangan daging teripang disebabkan daerah telopeptida molekul kolagen menjadi terbuka oleh larutan $\mathrm{NaOH}$, sehingga air dapat mengeluarkan protein bukan kolagen dari matrik kolagen (Jaswir et al. 2011). Larutan basa $\mathrm{NaOH}$ selanjutnya dianalisis kadar protein dengan uji Bradford. Kadar protein dari larutan $\mathrm{NaOH}$ sisa pra-perlakuan menunjukkan penurunan seiring bertambahnya waktu perendaman. Hal ini menunjukkan protein nonkolagen larut pada larutan $\mathrm{NaOH}$ setiap bertambahnya waktu perendaman. Larutan basa berfungsi untuk melarutkan protein non kolagen dan safonikasi lemak yang terikat pada serat kolagen sehingga lemak akan keluar dari daging teripang (Zhou dan Regenstein 2005).

Table 1 Concentrations of non-collagen protein in $\mathrm{NaOH}$ solution

\begin{tabular}{cc}
\hline Hour to & Concentration $(\mathrm{mg} / \mathrm{mL})$ \\
\hline 6 & 0.107 \\
12 & 0.088 \\
18 & 0.052 \\
24 & 0.050 \\
30 & 0.047 \\
36 & 0.038 \\
42 & 0.037 \\
48 & 0.023 \\
\hline
\end{tabular}


Proses netralisasi dengan akuades dilakukan setelah pra-perlakuan dengan tujuan menghilangkan sisa-sisa bahan yang bukan kolagen pada daging teripang sehingga tidak memengaruhi $\mathrm{pH}$ asam asetat saat isolasi. Asam asetat digunakan untuk menghidrolisis kolagen daging teripang menjadi sederhana. Penggunaan larutan asam akan meningkatkan ion $\mathrm{H}^{+}$sehingga air masuk menuju struktur daging teripang dengan ikatan elektrostatik antar gugus polar pada kolagen daging teripang dengan ion $\mathrm{H}^{+}$yang berasal dari asam asetat. Asam asetat dapat mengubah struktur tersier kolagen dengan memutuskan ikatan ionic sehingga kolagen dapat larut (Jaswir et al. 2011). Jumlah kolagen yang terekstrak menggunakan asam sitrat dan asam klorida akan lebih rendah jika dibandingkan dengan menggunakan asam asetat. Hal ini karena asam asetat dapat memutus untai antar ikatan silang pada kolagen sehingga melarutkan kolagen yang tidak berikatan silang (Kasim 2013; Liu et al. 2015). Kolagen dapat larut sempurna menggunakan $\mathrm{CH}_{3} \mathrm{COOH}$ 0,5 M (Liu et al. 2015). Konsentrasi asam asetat mengubah derajat keasaman $(\mathrm{pH})$, sehingga dapat mengubah kerapatan muatan kolagen melalui interaksi elektrostatik dan berdampak pada perubahan struktur protein yang dapat meningkatkan kelarutan kolagen. Setelah proses ekstraksi, suspensi hasil perendaman dengan asam asetat disaring dan diperoleh filtrat kolagen cair. Kolagen cair dikeringbekukan dengan freeze dryer untuk diperoleh kolagen padat. Kolagen padat yang diperoleh dihitung rendemen untuk mengetahui banyaknya kolagen yang dihasilkan dari bahan baku dan keefektifan metode isolasi dan dikarekterisasi sifat fisikokimia kolagen teripang gama.

Nilai rendemen kolagen daging teripang gama yang didapatkan $2,43 \%$ (b/b) dan rendah dibandingkan dengan penelitian Yusida (2016) sebesar 2,54\%, namun lebih tinggi dibandingkan dengan Damayanti (2017) $2,24 \%$. Rendemen kolagen dipengaruhi oleh jenis bahan baku yang digunakan. Rendemen kolagen teripang gama yang dihasilkan lebih rendah dibandingkan dengan jenis teripang pasir (Holothuria scabra) 2,49\% (Pamungkas 2014), tetapi lebih tinggi dibandingkan dengan jenis teripang emas (S. hermanni) $0,66 \%$ (Safithri et. al 2018). Perbedaan nilai rendemen dikarenakan oleh cara isolasi kolagen yang digunakan berbeda. Faktor lain yang memengaruhi perbedaan nilai rendemen di antaranya yaitu perbedaan konsentrasi larutan untuk menghilangkan protein nonkolagen dan konsentrasi larutan asam untuk ekstraksi kolagen, bahan baku yang digunakan, suhu, dan waktu yang dipakai dalam proses ekstraksi (Potaros et al. 2009). Isolasi kolagen menggunakan enzim menghasilkan nilai rendemen yang lebih besar (Cui et al. 2007; Park et al. 2012; Siddiqui et al. 2013). Ekstraksi kolagen dengan modifikasi asam-enzim mampu menghasilkan rendemen kolagen yang lebih tinggi. Hal ini disebabkan karena enzim mampu memutus ikatan peptida dan ikatan silang pada ujung nonheliks kolagen. Selain itu ujung telopeptida pada rantai polimer juga terputus sehingga kelarutan kolagen dalam pelarut asam menjadi meningkat (Schrieber dan Gareis 2007).

\section{Karakter Fisikokimia Kolagen Daging Teripang Gama}

Nilai $\mathrm{pH}$ kolagen daging teripang gama yaitu 6,12 yang lebih besar dibandingkan nilai pH yang dilaporkan Fawzya et al. (2016) 6,08, namun lebih kecil dibandingkan hasil riset Alhana et al. (2015) dengan nilai $\mathrm{pH}$ 7,37. Perbedaan nilai $\mathrm{pH}$ dipengaruhi oleh metode ekstraksi dan konsentrasi asam asetat yang digunakan juga berbeda-beda. Penggunaan $\mathrm{CH}_{3} \mathrm{COOH}$ 0,5 M memiliki nilai $\mathrm{pH}$ larutan yang lebih asam dibandingkan asam asetat yang digunakan pada metode ekstraksi dengan air sebesar 0,1-0,3\% (Alhana et al. 2015). Metode ekstraksi menggunakan air melakukan tahapan penetralan setelah perendaman dengan asam asetat sedangkan metode kolagen larut air tidak dilakukan penetralan. Menurut BSN (2014) nilai pH kolagen berkisar 6,5-8,0. Nilai $\mathrm{pH}$ kolagen hasil tidak masuk dalam rentang nilai $\mathrm{pH}$ standar mutu kolagen, namun, jika kolagen diaplikasikan pada industri kosmetik maka nilai $\mathrm{pH}$ kolagen teripang gama masih dapat diterima karena syarat untuk $\mathrm{pH}$ kolagen berada pada rentang 3,8-4,7 (Peng et al. 2004). 
Viskositas kolagen daging teripang gama yaitu 5,37 $\pm 0,06 \mathrm{cP}$. Kolagen hasil memiliki nilai viskositas lebih rendah dibandingkan penelitian Alhana (2015). Nilai viskositas dipengaruhi pergerakan molekul dalam larutan (Nishimoto et al. 2005). Bobot molekul kolagen hasil isolasidapat memengaruhi nilai viskositas (Ogawa et al. 2004). Semakin besar bobot molekul maka pergerakan molekul dalam suatu larutan semakin berkurang sehingga berdampak pada nilai viskositas yang lebih besar (Mariod dan Adam 2013). Faktor-faktor yang dapat mengubah nilai viskositas antara lain jumlah molekul terlarut, temperatur, dan gaya tarik antar molekul (Zhang et al. 2011). Selain nilai pH dan viskositas, sifat fisik kolagen yang harus diketahui adalah derajat putih.

Derajat putih kolagen daging teripang gama yang diperoleh adalah sebesar $61,83 \pm 1,14 \%$. Nilai tersebut lebih kecil jika dibandingkan dengan derajat putih kolagen teripang gama sebesar $69,01 \%$ yang diekstraksi menggunakan air (Alhana et al 2015). Derajat putih kolagen hasil lebih rendah dapat disebabkan oleh preparasi sampel yang kurang maksimal memisahkan daging dengan kulit sehingga pigmen kulit masih terdapat pada daging teripang. Derajat putih kolagen yang rendah juga dipengaruhi oleh keefektifan dalam melarutkan pigmen selama praperlakuan. Jaswir et al. (2011) menyatakan bahwa perendaman dengan larutan basa menyebabkan pengembangan pada daging sehingga pigmen dalam daging akan mudah dieliminasi dan dikeluarkan.

\section{Spektrum Gugus Fungsi Kolagen}

Spektrum protein kolagen daging teripang gama menunjukkan puncak serapan khusus pada wilayah-wilayah amida yaitu I, II, III, A, dan B (Figure 1 dan Table 2). Bilangan gelombang amida $\mathrm{A}$ protein kolagen yang diesktraksi adalah 3406,29 $\mathrm{cm}^{-1}$ dan kolagen standar yaitu $3332,99 \mathrm{~cm}^{-1}$. Amida A protein kolagen teripang gama bergeser kearah kiri atau kearah yang lebih besar. Erizal et al. (2012) menyatakan bahwa kisaran wilayah Amida A berada pada $3440-3400 \mathrm{~cm}^{-1}$ mengidentifikasi vibrasi regangan $\mathrm{NH}$ dan ikatan hidrogen. Keberadaan daerah amida A dapat dipengaruhi oleh gugus $\mathrm{OH}$ yang menunjukkan peran aktif molekul air pada kolagen. Puncak amida B kolagen teripang gama terletak pada bilangan gelombang $2920,22 \mathrm{~cm}^{-1}$ dan tidak berbeda jauh dengan kolagen standar $2924,09 \mathrm{~cm}^{-1}$. Kisaran wilayah Amida B berada pada $2935-2915 \mathrm{~cm}^{-1}$ dan mengidentifikasi regangan $\mathrm{CH}_{2}$ (Coates 2000). Jika dilihat bentuk ketajaman peak amida

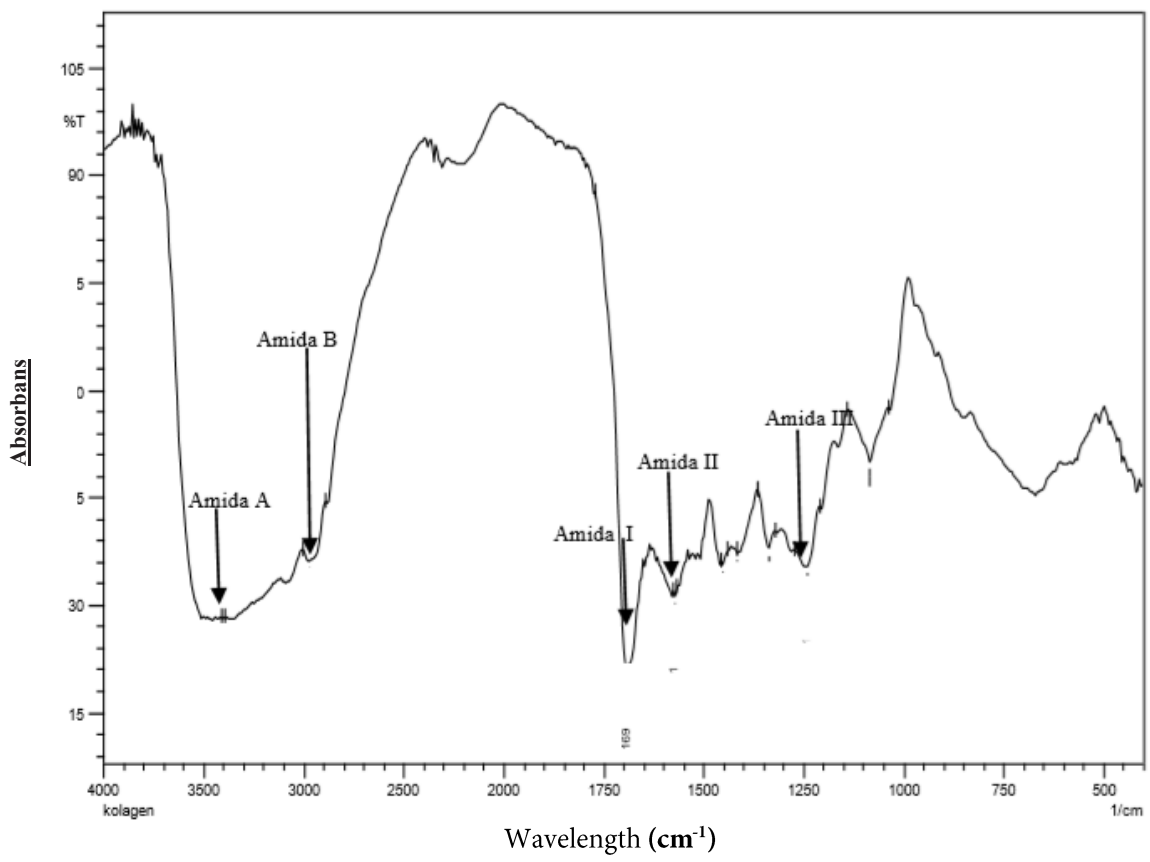

Figure 1 Infrared spectrum of Stichopus variegatus acid solution collagen 
Table 2 Characteristics of collagen functional groups

\begin{tabular}{|c|c|c|c|c|}
\hline \multirow[b]{2}{*}{ Tipe Amide } & \multicolumn{3}{|c|}{ Peak absorbancy of wave number $\left(\mathrm{cm}^{-1}\right)$} & \multirow[b]{2}{*}{$\begin{array}{l}\text { Characteristics } \\
\text { Amide }\end{array}$} \\
\hline & $\begin{array}{c}\text { Acquired } \\
\text { absorbancy }\end{array}$ & $\begin{array}{c}\text { Standard of } \\
\text { absorbancy } \\
\text { area }\end{array}$ & $\begin{array}{l}\text { Collagen } \\
\text { Standard }\end{array}$ & \\
\hline Amide A & 3406,29 & $3350-3550^{1}$ & 3332,99 & NH stretching ${ }^{1}$ \\
\hline Amide B & 2920,22 & $2935-2915^{2}$ & 2924,09 & $\begin{array}{c}\mathrm{CH}_{2} \\
\text { asymmetric } \\
\text { stertching }\end{array}$ \\
\hline Amide I & 1657,91 & $1600-1700^{3}$ & 1647,21 & $\mathrm{C}=\mathrm{O}$ stetching ${ }^{3}$ \\
\hline Amide II & 1571,99 & $1480-1575^{3}$ & 1546,91 & $\begin{array}{l}\mathrm{NH} \text { bending, } \\
\mathrm{CN} \text { stetching }\end{array}$ \\
\hline Amide III & 1242,16 & $1229-1301^{3}$ & 1334,74 & $\begin{array}{l}\mathrm{NH} \text { bending, } \\
\mathrm{CN} \text { stetching }\end{array}$ \\
\hline
\end{tabular}

$B$ pada kolagen teripang gama dan kolagen standar, peak amida B kolagen standar lebih tajam dibandingkan peak amida B kolagen teripang gama. Hal ini mengindikasikan kemurnian kolagen teripang gama sangat rendah, dan masih banyak pengotor yang menyebabkan bentuk peak amida B yang dihasilkan tidak tajam.

Amida I protein kolagen teripang berada pada $1657,91 \mathrm{~cm}^{-1}$ dan kolagen standar 1647,21 $\mathrm{cm}^{-1}$. Kisaran wilayah Amida I berada pada $1700-1600 \mathrm{~cm}^{-1}$ yang mengidentifikasi vibrasi regangan $\mathrm{C}=\mathrm{O}$. Spektra struktur sekunder pada gugus amida terletak pada serapan 1700$1660 \mathrm{~cm}^{-1}$ (turns), 1654-1650 cm $\mathrm{cm}^{-1}$ (helix), $1644-1640 \mathrm{~cm}^{-1}$ (rancom coil), dan 1640-1620 $\mathrm{cm}^{-1}$ (sheet) (Kong dan Yu 2007). Dengan demikian, kolagen teripang gama dan kolagen standar memiliki kesamaan struktur sekunder yaitu adanya struktur sekunder helix. Amida I berkorelasi erat dengan struktur sekunder protein (Muyonga et al. 2004).

Puncak amida II kolagen teripang gama terletak pada bilangan gelombang sebesar $1571,99 \mathrm{~cm}^{-1}$ dan kolagen standar $1546,91 \mathrm{~cm}^{-1}$. Kisaran wilayah amida II berada pada 1575$1480 \mathrm{~cm}^{-1}$ dan menunjukkan adanya vibrasi tekuk $\mathrm{NH}$ dan regangan $\mathrm{CN}$ (Kong dan $\mathrm{Yu}$ 2007).

Kisaran wilayah amida III berada pada $1301-1229 \mathrm{~cm}^{-1}$ dan mengidentifikasi interaksi intermolekuler kolagen yang berhubungan dengan tekuk NH dan regangan $\mathrm{CN}$ (Kong dan
Yu 2007). Amida III protein kolagen teripang pada1242,16 $\mathrm{cm}^{-1}$ dan kolagen standar 1334,74 $\mathrm{cm}^{-1}$ (Table 2). Rasio antara Amida III protein kolagen teripang dengan serapan $1450 \mathrm{~cm}^{-1}$ yaitu 1,03 . Hal ini menunjukkan terdapatnya struktur tripel heliks yang mengindikasikan kolagen teripang belum terdegradasi menjadi bentuk gelatin karena nilainya mendekati 1. Nilai intensitas rasio 0,59 mengindikasi kolagen terdenaturasi dan hilangnya struktur tripel heliks sehingga menjadi gelatin (Nikoo et al. 2011).

\section{Asam Amino Kolagen}

Kolagen daging teripang gama memiliki 4 jenis asam amino terbanyak yaitu glisina $(12,63 \%)$, diikuti dengan asam glutamat $(12,16 \%)$, lisin (11,54\%), dan alanina $(10,61 \%)$. Tiga kadar asam amino terendah yaitu histidina $(0,09 \%)$, fenilalanina $(2,84 \%)$ dan tirosina (3,26\%) (Table 3). Glisina adalah asam amino terbanyak dalam kolagen. Komposisi asam amino kolagen teripang gama tertinggi adalah glisin (16,88\%) (Fawzya et al. 2016). Aberoumand (2012) yang menyatakan proporsi glisina lebih banyak dibandingkan asam amino lainnya pada kolagen, karena di setiap tiga residu asam amino pada kolagen terdapat glisina dan berada ditengah pada rantai $\alpha$, serta berperan membentuk kolagen pada rantai alfa tripel heliks (Matmaroh et al. 2011). Alanina dan prolina adalah asam amino pembentuk kolagen selain glisina. Berdasarkan 
hasil analisis, kolagen teripang gama memiliki asam amino alanina $(10,61 \%)$ dan prolina $(6,80 \%)$. Asam amino daging teripang gama memiliki nilai sangat rendah adalah histidina dan tirosina. Kolagen tidak mengandung asam amino triptofan dan sisteina, dan kolagen memiliki kadar asam amino histidina dan tirosina yang rendah. Bahan baku kolagen yang sama dapat menyebabkan perbedaan komposisi asam amino penyusun kolagen. Hal ini dapat dikarenakan cara ekstraksi dan konsentrasi $\mathrm{CH}_{3} \mathrm{COOH}$ yang digunakan berbeda (Aberoudmand 2012). Nurhayati et al. (2013) menyatakan penggunaan $\mathrm{CH}_{3} \mathrm{COOH}$ konsentrasi yang tinggi akan memengaruhi proporsi asam amino dari kolagen dengan cara substitusi ion-ion sehingga dapat memutuskan struktur protein. Menurut Zeugolis et al. 2008) asam memiliki kinerja yang kuat untuk memecah ikatan-ikatan intermolekul rantai asam amino. Rantai asam amino tersebut mengalami denaturasi dan proses pelarutan sehingga mengalami kerusakan secara permanen.

\section{Stabilitas Termal}

Kurva termogram kolagen (Figure 2) menunjukkan bahwa kolagen memiliki 2 puncak eksotermik dan suhu denaturasi sebesar $48^{\circ} \mathrm{C}$. Titik eksotermik yang ke- 1 menunjukkan temperatur awal $82,9^{\circ} \mathrm{C}$, temperatur akhir pelelehan $92,6^{\circ} \mathrm{C}$, dan titik pelelehan $87,8^{\circ} \mathrm{C}$. Puncak eksotermik ke-2 menunjukkan suhu awal $156,9^{\circ} \mathrm{C}$, suhu akhir pelelehan $173,3^{\circ} \mathrm{C}$, dan titik pelelehan $162,4^{\circ} \mathrm{C}$. Data juga menunjukkan suatu reaksi eksoterm dengan nilai entalpi yang bernilai negatif yaitu $-5,04 \mathrm{~kJ} / \mathrm{g}$ dan $-457,3 \mathrm{~kJ} / \mathrm{g}$.

Analisis termal adalah pengukuran sifat kimia fisika untuk mengetahui fase-fase transisi pada polimer. Denaturasi protein dapat terjadi karena perubahan struktur kuartener, tersier, dan sekunder dari protein (Ogawa et al. 2004). Suhu denaturasi protein kolagen memiliki nilai sebesar $48^{\circ} \mathrm{C}$, hasil ini lebih tinggi dari yang dilaporkan Abedin et al. (2012) Stichopus vastus $25,23^{\circ} \mathrm{C}$ dan Safithri et al. (2019) Chirocentrus dorab $40^{\circ} \mathrm{C}$ serta lebih kecil dibandingkan Cui et al. (2007) Stichopus japonicus $57^{\circ} \mathrm{C}$. Suhu denaturasi yang tinggi lebih stabil terhadap panas sehingga jika diaplikasikan tidak mudah rusak dalam proses pembuatan produk. Perbedaan suhu denaturasi kolagen dipengaruhi oleh bahan baku yang digunakan, suhu lingkungan dan suhu biologis tubuh organisme tersebut (Ogawa et al. 2004).

Kurva termogram DSC kolagen (Figure 2) memiliki 2 puncak eksotermik yang ditunjukkan entalpi bernilai negatif. Puncak eksotermik pertama merupakan suhu transisi gelas (Tg) kolagen sebesar $87,8^{\circ} \mathrm{C}$ yang menunjukkan gelatinisasi kolagen karena putusnya ikatan hidrogen pada polimer amorf yaitu gelatin (Karim dan Bhat 2009). Puncak kedua merupakan nilai titik leleh $(\mathrm{Tm})$ yang menunjukkan polimer berwujud cair. Nilai Tm dari kolagen adalah $162.4^{\circ} \mathrm{C}$ dengan suhu

Table 3 Amino acid levels Stichopus variegatus acid soluble collagen

\begin{tabular}{cc}
\hline Jenis Asam amino & Konsentrasi (\%) \\
\hline Glycine & 12.63 \\
Glutamic acid & 12.16 \\
Arginine & 5.84 \\
Lysine & 11.54 \\
Alanine & 10.61 \\
Serine & 9.63 \\
Aspartic acid & 8.18 \\
Proline & 6.80 \\
Arginine & 5.84 \\
Threonine & 4.56 \\
Valine & 4.20 \\
Leucine Proline & 4.13 \\
Isoleucine & 3.53 \\
Tirosine & 3.26 \\
Phenylalanine & 2.84 \\
Histidine & 0.09 \\
\hline
\end{tabular}




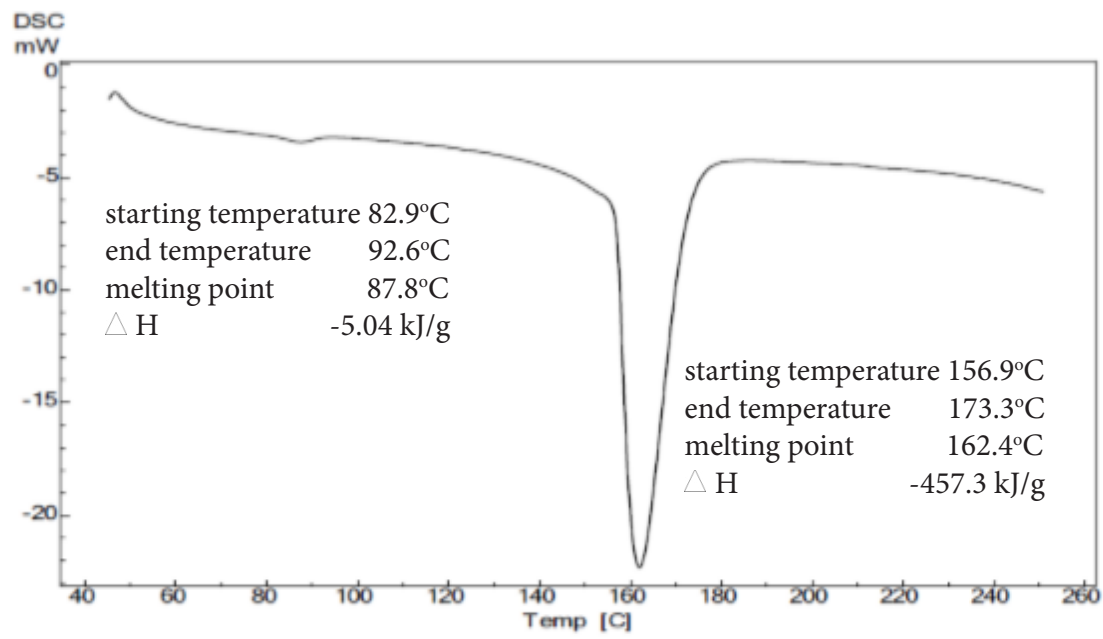

Figure 2 Thermogram of Stichopus variegatus acid soluble collagen

awal dan akhir pelelehan adalah $156,9^{\circ} \mathrm{C}$ dan $173,3^{\circ} \mathrm{C}$. suhu transisi gelas dan titik leleh kolagen hasil lebih rendah dibandingkan dengan penelitian Alhana (2015) yaitu $100,94^{\circ} \mathrm{C}$ dan $163,67^{\circ} \mathrm{C}$ dengan kolagen dari jenis bahan baku yang sama. Suhu transisi gelas dan titik leleh kolagen hasil lebih rendah disebabkan oleh pelarut ekstraksi yang dipakai berbeda. Isolasi protein kolegen teripang pada penelitian ini menggunakan asam asetat sebagai pengesktrak kolagen sedangkan Alhana et al. (2015) menggunakan metode ektrasi dengan air sebagai pelarut kolagen. Ikatan intramolekul yang merupakan penstabil struktur tripel heliks kolagen dapat terputus oleh asam asetat (Ahmad dan Benjakul 2010). Asam amino prolina dan hidroksiprolina dapat meningkatkan stabilitas termal dengan cara menjaga integritas struktural kolagen. Komposisi asam amino prolina (6,80\%) kolagen teripang pada penelitian ini lebih kecil jika dibandingkan dengan Alhana et al. (2015) yang memiliki kandungan prolina sebesar $7,41 \%$. Hal ini yang menyebabkan stabilitas termal kolagen hasil juga lebih rendah dibandingkan dengan penelitian Alhana et al. (2015). Asam amino prolina memiliki turunan yaitu hidroksiprolina. Prolina memiliki cincin pirolidin yang dapat menstabilkan struktur kuartener dan tersier rantai polipeptida protein sehingga tidak berubah menjadi struktur sekunder dan membantu menstabilkan rantai tripel heliks
(Bae et al. 2008; Zang et al. 2007). Gelse et al. (2003) mengemukakan hidroksiprolina membentuk ikatan hidrogen intramolekul dan membantu menjaga stabilitas termal pada rantai tripel heliks kolagen.

\section{KESIMPULAN}

Rendemen kolagen daging teripang gama yang diisolasi sebesar 2,43\%. Karakteristik fisik kolagen teripang gama menunjukkan nilai $\mathrm{pH}$ 6,12 , viskositas $5,37 \mathrm{cP}$, derajat putih $61,83 \%$, temperatur denaturasi $48^{\circ} \mathrm{C}$, temperatur transisi $87,8^{\circ} \mathrm{C}$, dan temperatur pelelehan $162,4^{\circ} \mathrm{C}$. Gugus fungsi dan komposisi asam amino kolagen yang diperoleh menunjukkan bahwa karakteristik kimia kolagen sudah sesuai.

\section{DAFTAR PUSTAKA}

[AOAC]. Association of Official Analytical Chemist. 2005. Official Methods of Analysis of the Association of Official Analytical Chemist. Virginia (US): The Association of Analytical Chemist, Inc.

[BSN] Badan Standardisasi Nasional. 2014. Kolagen kasar dari sisik ikan-Syarat mutu dan pengolahan: SNI 8076-2014. Jakarta (ID): Badan Standardisasi Nasional.

Abedin MZ, Karim AA, Ahmed F, Latiff AA, Gan CY, Ghazali FC, Sarker MDI. 2012. Isolation and characterization of pepsin-solubilized collagen from the integument of sea cucumber (Stichopus 
vastus). Journal of the Science of Food and Agriculture. 93(5): 1083-1088.

Aberoumand A. 2012. Comparative study between different methods of collagen extraction from fish and its properties. World Applied Science Journal. 16 (3): 316-319

Ahmad M, Benjakul S. 2010. Extraction and characterisation of pepsin solubilised collagen from the skin of unicorn leatherjacket (Aluterus monocerous). Food Chemistry. 120:817-824.

Alhana, Suptijah P, Tarman K. 2015. Ekstraksi dan karakterisasi kolagen dari daging teripang gamma (Stichopus variegatus). Jurnal Pengolahan Hasil Perikanan Indonesia. 18(2): 150-161.

Alhana. 2015. Ekstraksi dan karakterisasi kolagen dan nanokolagen dari daging teripang gamma (Stichopus variegatus) [Tesis]. Bogor (ID): Institut Pertanian Bogor.

Andirisnanti WA. 2012. Uji manfaat ekstraksi kolagen kasar dari teripang Stichopus hermanni sebagai bahan pelembab kulit [tesis]. Depok (ID): Universitas Indonesia

Astiana I, Nurjanah, Nurhayati T. 2016. Karakteristik kolagen larut asam dari kulit ikan ekor kuning. Jurnal Pengolahan Hasil Perikanan Indonesia. 19(1): 79-93.

Bae I, Osatomi K, Yoshida A, Osako K, Yamaguchi A, Hara K. 2008. Biochemical properties of acid-soluble collagens extracted from the skins of underutilised fishes. Food Chemistry. 108: 49-54.

Bradford MM. 1976. A rapid and sensitive method for quantitation of microgram quantities of protein utilizing the principle of protein-dye binding. Analitycal Biochemistry. 72(1): 248-254

Choi JH, Benham SH, Kim SM. 2013. Physicobiochemical characteristics of scallop mantle collagen soluble in pepsin. Journal Agricultural Science and Technology 15: 293-302

Coates J. 2000. Interpreration of infrared spectra, a practical approach: Meyers RA, editor. Encyclopedia of Analytical Chemistry. USA (US): John Wiley \& Sons Ltd.

Cui FX, Xue CH, Zhao JL, Zhang YQ, Dong P,
Fu XY, Gao X. 2007. Characterization and subunit composition of collagen from the body wall of sea cucumber Stichopus japonicas. Food Chemistry. 100: 11201125.

Damayanti R. 2017. Karakterisasi toner penyegar wajah berbasis kolahen teripang gamma (Stichopus variegatus) dan kitosan [skripsi]. Bogor (ID): Institut Pertanian Bogor.

Devi HLNA, Suptijah P, Nurilmala M. 2017. Efektifitas alkali dan asam terhadap mutu kolagen dari kulit ikan patin. Jurnal Pengolahan Hasil Perikanan Indonesia. 20(2): 255-265.

Djailani F, Trilaksani W, Nurhayati T. 2016. Optimasi ektraksi dan karakterisasi kolagen dari gelembung renang ikan cunang dengan metode asam-hidroekstraksi. Jurnal Pengolahan Hasil Perikanan Indonesia. 19(2): 156-167.

Erizal, Basril AR, Setyo AK, Sulistioso GS, Sudirman. 2012. Pengaruh iradiasi gamma pada sifat fisiko-kimia kolagen dalam larutan. Jurnal Sains Materi Indonesia. 15 (4): 221-225.

Fawzya YN, Chasanah E, Poernomo A, Khirzin MH. 2016. Isolasi dan karakterisasi parsial kolagen dari teripang gamma (Sticopus variegatus). Jurnal Pascapanen dan Bioteknologi Kelautan dan Perikanan. 11(1): 91-100

Gelse K, Poschlb E, Aigner T. 2003. Collagensstructure, function, and biosynthesis. Advanced Drug Delivery Reviews. 55: 1531-1546.

Hidayat AS, Siradj M. 2015. Sertifikasi halal dan sertifikasi non halal pada produk pangan industri. Ahkam. 15 (2): 199-210.

Jaswir I, Monsur HA, Salleh HM. 2011. Nanostructural analysis of fish collagen extracts for new process development. African Journal of Biotechnology. 10(81):1884718854

Karim AA, Bhat R. 2009. Fish gelatin: properties, challenges, and prospects as an alternative to mammalian gelatins. Food Hydrocolloids. 23:563-576

Kartika IWD, Trilksani W, Adnyane IKM. 2016. Karakterisasi kolagen dari limbah gelembung renang ikan cuanang 
(Muraenesox talabon) hasil ekstraksi asam dan hidrotermal. Jurnal Pengolahan Hasil Perikanan Indonesia. 19(3): 222-232

Kasim S. 2013. Pengaruh variasi jenis pelarut asam pada ekstraksi kolagen ikan pari (Himantura gerrardi) dan ikan tuna (Thunnus sp.). Majalah Farmasi dan Farmakologi. 17(2): 35-38.

Kong J, Yu S. 2007. Fourier transform infrared spectroscopic analysis of protein secondary structures. Acta Biochimica et Biophysca Sinica. 39(8): 549-559

Liu D, Wei G, Li T, Hua J, Lu J, Regenstein JM, Zhou P. 2015. Effects of alkaline pretreatments and acid extraction conditions on the acid-soluble collagen from grass carp (Ctenopharyngodonidella) skin. Food Chemistry. 172:836-843

Mariod AA, Adam HF. 2013. Review: gelatin, source, extraction and industrial applications. Acta Scientiarum Polonorum Technologia Alimentaria 12 (2): 135-147.

Martianingsih N, Atmaja L. 2009. Analisis sifat kimia, fisik, dan termal gelatin dari ekstraksi kulit Ikan pari (Himantura gerrardi) melalui variasi jenis larutan asam. Prosiding KIMIA FMIPA - ITS.

Matmaroh K, Benjakul S, Prodpran T, Encarnacion AB, Kishimura H. 2011. Characteristics of acid soluble collagen and pepsin soluble collagen from scale of spotted golden goatfish (Parupeneus heptacanthus). Food Chemistry.129: 11791186.

Nikoo M, Xu X, Benjakul S, Xu G, RamiresSuarez JC, Ehsani A, Kasankala LM, Duan X, Abass S. 2011. Characterization of gelatin from the skin of farmed Amur sturgeon Acipenser schrenckii. International Aquatic Research 3(2): 135145.

Nishimoto M, Sakamoto R, Mizuta S, Yoshinaka R. 2005. Identification and characterization of molecular species of collagen in ordinary muscle and skin of the Japanese flounder (Paralichthys olivaceus). Journal Food Chemistry. 90 (12): 151-156.

Nurhayati, Tazwir, Murniyati. 2013. Ekstraksi dan karakterisasi kolagen larut asam dari kulit ikan nila (Oreochromis niloticus).
JPB Kelautan dan Perikanan. 8 (1): 85-92.

Nurilmala M, Pertiwi RM, Nurhayati T, Fauzi S, Batubara I, Ochiai Y. 2019. Characterization of collagen and its hydrolysate from yellowfin tuna Thunnus albacares skin and their potencies as antioxidant and antiglycation agents. Fisheries Science. 85(3): 591-599.

Ogawa M, Portier JR, Moody MW, Bell J, Schexnayder MA, Losso JN. 2004. Biochemical properties of bone and scale collagens isolated from the subtropical fish black drum (Pogonia cromis) and sheepshead sea bream (Archosargus probatocephalus). Food Chemistry. 88: 495-501

Pamungkas TH. 2014. Kajian potensi collagen pada teripang pasir (Holothuria scabra) dari Pulau Pramuka Kepulauan Seribu [skripsi]. Bogor (ID): Institut Pertanian Bogor.

Pamungkas BF, Supriyadi, Murdiati A, Indrati R. 2018. Ekstraksi dan karakterisasi kolagen larut asam dan pepsin dari sisik haruan (Channa striatus) kering. Jurnal Pengolahan Hasil Perikanan Indonesia. 21(3): 513-521

Park JW. 2005. Ingredient technology for surimi and surimi seafood. Di dalam: Park JW, editor. Surimi and Surimi Seafood (Second Edition). Boca Raton (US): CRC Press.

Park SY, Hee KL, Seogjae L, Hyeong CH, Somi KC, Moonjae C. 2012. Pepsin solubilized collagen (PSC) from red sea cucumber (Stichopus japonicas) regulates cell cycle and fibronectin synthesis in HaCaT cell migration. Food Chemistry. 132: 487-492.

Peng Y, Glattauer V, Werkmeister JA, Ramshaw JAM. 2004. Evaluation for collagen products for cosmetic application. Journal of Cosmestic Science. 55:327-341.

Potaros T, RaksakulthaiN, Runglerdkreangkrai J, Worawattanamateekul W. 2009. Characteristics of collagen from nile tilapia (Oreochromis niloticus) skin isolated by two different methods. Kasetsart Journal-Natural Science. 43(3): 584-593.

Purcell SW. 2014. Processing Sea Cucumber into Beche-de-mer: A Manual for Pacific 
Island Fishers. Auckland (NZ): Stredder Print Ltd.

Safithri M, Tarman K, Suptijah P, Widowati N. 2019. Karakteristik Fisikokimia Kolagen Larut Asam Dari Kulit Ikan ParangParang (Chirocentrus dorab). Jurnal Pengolahan Hasil Perikanan Indonesia. 22(3): 441-452

Safithri M, Setyaningsih I, Tarman K, Suptijah P, Yuhendri VM, Meydia. 2018. Potensi Kolagen Teripang Emas Sebagai Inhibitor Tirosinase. Jurnal Pengolahan Hasil Perikanan Indonesia. 21(2):295-303

Schrieber R, Gareis H. 2007. Gelatin Handbook. Theory and Industrial Practice. Germany (DE): Wiley-VCH Verlag GmbH \& Co.

Siddiqui YD, Arief EM, Yusoff A, Suzina AH, Abdullah SY. 2013. Isolation of pepsin solubilized collagen (PSC) from crude collagen extracted from body wall of sea cucumber (Bohadschia spp.). International Journal of Pharmacy and Pharmaceutical Sciences. 5(2): 555-559.

Silvipriya KS, Kumar KK, Bhat AR, Kumar BD, Jhon A, Lakshmanan P. 2015. Collagen: animal sources and biomedical application. Journal of Applied Pharmaceutical Science. 5(3): 123-127.

Simamora GRR, Trilaksani W, Uju. 2019. Profiling kolagen gelembung renang ikan patin (Pangasius sp.) melalui proses enzimatis. Jurnal Pengolahan Hasil Perikanan Indonesia. 22(2): 299-310.

Sitepu GSB, Santoso J, Trilaksani W. 2019. Kolagen gelembung renang ikan patin (Pangasius sp.) hasil ekstraksi asam.
Jurnal Pengolahan Hasil Perikanan Indonesia. 22(2): 327-339.

Wulandari, Suptijah P, Tarman K. 2015. Efektivitas pretreatment alkali dan hidrolisis asam asetat terhadap karakteristik kolagen dari kulit ikan gabus. Jurnal Pengolahan dan hasil Perikanan Indonesia. 18(3): 287-302.

Yan M, Li B, Zhao X, RenG, Zhuang Y, Hou H, Zhang X, Chen L, Fan Y. 2008. Characterization of acid soluble collagen from the skin of walleye Pollock (Theragra chalcogramma). Food Chemistry. 107: 1581-1586

Yusida A. 2016. Formula sediaan krim berbasis nanokolagen teripang gamma (Stichopus variegatus) [skripsi]. Bogor (ID): Institut Pertanian Bogor.

Zang Y, Liu W, Li G, Shi B, Miao Y, Wu X. 2007. Isolation and partial characterization of pepsin-soluble collagen from the skin of grass carp (Ctenopharyngodon idella). Food Chemistry. 103: 906-912.

Zeugolis DI, Khew ST, Yew ESY, Ekaputra AK, Tong YW, Yung LL, Hutmacher DW, Sheppard C, Michael. 2008. Electrospinning of pure collagen nano-fibres Just an expensive way to make gelatin. Biomaterials. 15 (1): 2293-2305.

Zhang F, Wang A, Li Z, He S, Shao L. 2011. Preparation and characterisation of collagen from freshwater fish scales. Food and Nutrition Sci. 2:818- 823.

Zhou P, Regenstein JM. 2005. Effects of alkaline and acid pretreatments on Alaska pollock skin gelatin extraction. Journal of Food Science. 70(6):392396. 